\title{
Spontaneous Deletions in the TOL Plasmid pWW20 which Give Rise to the B3 Regulatory Mutants of Pseudomonas putida MT20
}

\author{
By ROGER W. PICKUP AND PETER A. WILLIAMS* \\ Department of Biochemistry and Soil Science, University College of North Wales, Bangor, \\ Gwynedd LL57 2UW, U.K.
}

(Received 14 September 1981; revised 10 November 1981)

\begin{abstract}
The size of the TOL plasmid pWW20 from Pseudomonas putida MT20, as measured by analysis of agarose electrophoresis gels after restriction endonuclease hydrolysis, was 270-280 kilobase pairs (kb). During growth on benzoate, MT20 segregates strains carrying mutations in the plasmid regulatory gene $x y l S$; these so-called B3 strains retain the ability to grow on $m$-xylene $\left(\mathrm{Mxy}^{+}\right)$but do not grow on its metabolite $m$-toluate ( $\left.\mathrm{Mtol}^{-}\right)$and have also lost the ability to transfer the plasmid ( $\left.\mathrm{Tra}^{-}\right)$. Analysis of restriction digests of plasmid DNA from seven such segregants, independently isolated, showed that pWW20 had undergone extensive deletions of $90-100 \mathrm{~kb}$. All the deleted plasmids had lost a common core of DNA, of about $72-80 \mathrm{~kb}$, but in class A mutants the deletion extended at one end of this core and in class B mutants at the other end. Class A and B mutants also differed in their rate of growth on $m$-xylene as a result of differences in the level of expression of their plasmid-coded catabolic enzymes. This suggests that an additional gene, involved in regulating levels of gene expression, is located in the region uniquely deleted in the class B mutants.
\end{abstract}

\section{INTRODUCTION}

Pseudomonas putida MT20 carries a TOL plasmid, pWW20 (originally called TOL20), which encodes enzymes for the catabolism of toluene, $m$-xylene and $p$-xylene through benzoate, $m$-toluate and $p$-toluate, respectively, followed by the meta pathway for assimilation of the aromatic ring (Fig. 1) (Williams \& Murray, 1974; Williams \& Worsey, 1976; Worsey \& Williams, 1975). As with strains carrying other isofunctional TOL plasmids (Williams \& Murray, 1974; Williams \& Worsey, 1976), growth in benzoate-minimal medium selects for spontaneous segregants which have lost the expression of the TOL pathway, but which catabolize benzoate by the chromosomal $\beta$-ketoadipate (or ortho) pathway; this pathway is ubiquitous in Pseudomonas hosts, is not induced in the presence of a TOL plasmid (Williams \& Murray, 1974; Williams \& Worsey, 1976), and supports a faster growth rate than does the plasmid pathway which accounts for its selection (Williams \& Worsey, 1976; Worsey \& Williams, 1977). With most of the TOL plasmids studied, benzoate selection produces segregants which no longer grow on any of the TOL substrates, except benzoate, and are routinely tested as $\mathrm{Ben}^{+} \mathrm{Mxy}^{-} \mathrm{Mtol}^{-}$(unable to grow on $m$-xylene or $m$-toluate). With the archetype TOL plasmid, pWW0, this phenotype can result, with about equal frequency, either from total loss of the plasmid or from the specific excision of a 39 kilobase pairs $(\mathrm{kb})$ section from the $117 \mathrm{~kb}$ plasmid (Bayley et al., 1977). Strain MT20 is one of a small group of strains which on benzoate selection give rise not only to $\mathrm{Ben}^{+} \mathrm{Mxy}^{-} \mathrm{Mtol}^{-}$segregants but also to a novel class we have called the B3 strains (Williams \& Worsey, 1976). These grow on the hydrocarbons by the complete TOL pathway, do not grow on $m$ - or $p$-toluate, but grow on benzoate via the $\beta$-ketoadipate pathway, and are routinely tested as $\mathrm{Ben}^{+} \mathrm{Mxy}^{+} \mathrm{Mtol}^{-}$ (Williams \& Worsey, 1976). In a detailed genetic and biochemical analysis of one such 


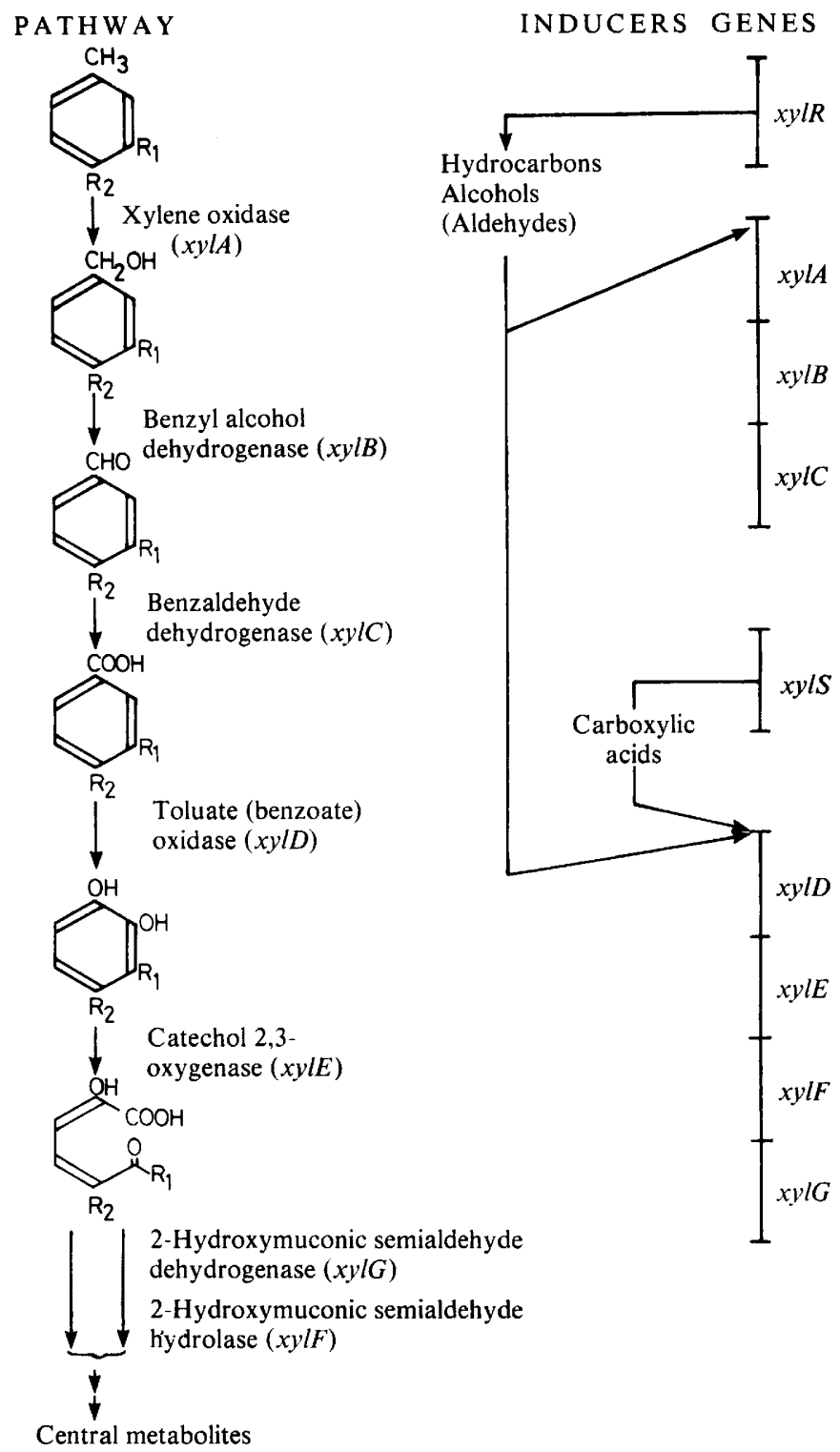

Fig. 1. The early enzymes of the TOL plasmid degradative pathway and their regulation. The primary metabolites of the pathway are toluene $\left(\mathbf{R}_{1}=\mathbf{R}_{2}=\mathrm{H}\right), m$-xylene $\left(\mathbf{R}_{1}=\mathrm{CH}_{3}, \mathbf{R}_{2}=\mathbf{H}\right)$ and $p$-xylene $\left(\mathbf{R}_{1}\right.$ $\left.=\mathrm{H}, \mathrm{R}_{2}=\mathrm{CH}_{3}\right) ; m$-toluate is the carboxylic acid metabolite of $m$-xylene. The regulatory model has been proposed from a study of pWW0 (Worsey et al., 1978), but essentially the same model was proposed for pWW20 (Worsey \& Williams, 1977) except that the regulation of $x y l A$ was not studied in this latter case. In the model, the hydrocarbon and alcohol substrates combine with the gene product of $x y l R$ to induce both $x y l A B C$ and $x y l D E F G$, whereas the carboxylic acids induce only the latter operon through the $x y l S$ gene product.

segregant (Worsey \& Williams, 1977) we proposed that it was the result of the deletion of a regulatory gene corresponding to $x y l S$ (but originally referred to as R2; Fig. 1). The resultant plasmid had become non-conjugative in contrast to the wild-type plasmid, suggesting that essential tra gene(s) had also been deleted. Until recently, pWW20 plasmid DNA has proved refractory towards extraction by any of the methods previously used for degradative 
plasmids. However, isolation of this DNA has now been achieved using a rapid method of preparation (Wheatcroft \& Williams, 1981), and we have compared the structures of pWW20 and seven of its deletion derivatives.

\section{METHODS}

Maintenance and growth of cultures. Strains PaW1 (Pseudomonas putida mt-2, ATCC 33015) and P. putida MT20 were maintained on minimal salts agar containing $5 \mathrm{~mm}-m$-toluate. The mutant B3 derivatives of strain MT20 were maintained on nutrient agar. Batch cultures in 2 litre minimal medium containing $10 \mathrm{mM}$-acetate were inoculated with $50 \mathrm{ml}$ nutrient broth-grown starter cultures and incubated for $24 \mathrm{~h}$ at $30^{\circ} \mathrm{C}$ under forced aeration. Inducing substrates were present from the start either in solution or, for $m$-xylene, as saturated vapour in the air supply.

Preparation of extracts. Cells were harvested by centrifugation for $1 \mathrm{~h}$ at $1000 \mathrm{~g}$, washed in $0.1 \mathrm{M}$-phosphate buffer, $\mathrm{pH} 7 \cdot 5$, centrifuged a second time and stored in two aliquots at $-20^{\circ} \mathrm{C}$. The frozen cells were resuspended in $5 \mathrm{ml}$ of either $0.1 \mathrm{M}$-phosphate buffer, pH 7.5, supplemented with $10 \%$ acetone (for assay of catechol 2,3-oxygenase) or phosphate $/ \mathrm{NaCl} / \mathrm{MgSO}_{4}$ (Worsey \& Williams, 1975) (for assay of benzyl alcohol dehydrogenase and benzaldehyde dehydrogenase) and sonicated for six periods of $30 \mathrm{~s}$ at $0{ }^{\circ} \mathrm{C}$ in an MSE $100 \mathrm{~W}$ ultrasonic disintegrator. Cell debris was removed by centrifugation at $150000 \mathrm{~g}$ for $6 \mathrm{~min}$ at $4{ }^{\circ} \mathrm{C}$.

Enzyme assays. The following enzymes were assayed as described by Worsey \& Williams (1975): benzyl alcohol dehydrogenase, substrate benzyl alcohol; benzaldehyde dehydrogenase (EC 1.2.1.28), substrate benzaldehyde; catechol 2,3-oxygenase (EC 1.13.11.2), substrate catechol. Protein was determined by the biuret method.

Plasmid isolation and digestion. Plasmid DNA was isolated by the preparative method of Wheatcroft \& Williams (1981) and was digested by restriction endonucleases (Uniscience, Cambridge, U.K.) according to the supplier's instructions. Gels containing $0.7 \mathrm{~g}$ agarose and $100 \mu \mathrm{g}$ ethidium bromide in $100 \mathrm{ml}$ of electrophoresis buffer were run submerged in electrophoresis buffer at $34-40 \mathrm{~mA}$ for $16-24 \mathrm{~h}$ and visualized as described previously (Wheatcroft \& Williams, 1981).

Sizing of plasmids. Restriction enzyme digests of plasmids were always run beside XhoI digests of pWW0, the fragments of which have been accurately sized (Downing \& Broda, 1979). Each plasmid was digested at least ten times and run for different lengths of time to resolve the larger or the smaller fragments. Interpretation of bands as double or triple bands was carried out by visual comparison of bands with adjacent bands in the same digests.

Benzoate curing. The B3 mutants of strain MT20 were prepared by growth on benzoate-minimal medium as described by Williams \& Worsey (1976).

\section{RESULTS AND DISCUSSION}

We isolated seven independent B3 segregants of $P$. putida MT20 after growth in benzoate-minimal medium for 15-20 generations. All had the B3 phenotype (Ben ${ }^{+} \mathrm{Mxy}^{+} \mathrm{Mtol}^{-}$) but they differed in their rate of growth on $m$-xylene. Class A strains (MT20-22, MT20-23, MT20-27) grew as fast on $m$-xylene as did the wild-type MT20, but class B strains (MT20-21, MT20-24, MT20-25, MT20-26) grew more slowly and patches or colonies took several days to appear. Three of the TOL catabolic enzymes were assayed under different induction conditions in two representatives of each class (Table 1); benzyl alcohol dehydrogenase and benzaldehyde dehydrogenase were chosen as representative of the early enzymes under control of $x y l R$ only, and catechol 2,3-oxygenase as representative of the later enzymes controlled by both $x y l R$ and $x y l S$. Both classes of mutants showed the same general induction pattern as described for the original B3 mutant (Worsey \& Williams, 1977). Growth in the presence of $m$-toluate caused no induction of any of the enzymes, whereas growth on $m$-xylene induced all three enzymes assayed. This pattern differed from that for strain MT20 in which $m$-toluate induced catechol 2,3-oxygenase but not benzyl alcohol dehydrogenase or benzaldehyde dehydrogenase. However, class A strains had fully induced levels of all three enzymes after growth on $m$-xylene, whereas class B strains had only about $10-30 \%$ of the fully induced levels of benzyl alcohol dehydrogenase and benzaldehyde dehydrogenase found in strain MT20, although catechol 2,3-oxygenase was fully induced. The uninduced levels of all three enzymes were also much reduced in class B mutants. 
Table 1. Enzyme specific activities in extracts of strains of P. putida MT20

\begin{tabular}{clrrrrr} 
& & \multicolumn{5}{c}{ Specific activity [mU (mg protein) $\left.{ }^{-1}\right]^{*}$} \\
Enzyme & Inducer & Strain ...MT20 & MT20-22 & MT20-27 & MT20-25 & MT20-26 \\
Benzyl alcohol & $m$-Xylene & 2270 & 3970 & 1630 & 290 & 500 \\
dehydrogenase & $m$-Toluate & 80 & 60 & 40 & 10 & 7 \\
& None & 50 & 90 & 100 & 5 & 7 \\
Benzaldehyde & $m$-Xylene & 700 & 1000 & 1310 & 250 & 250 \\
dehydrogenase & $m$-Toluate & 50 & 50 & 20 & 10 & 5 \\
& None & 30 & 40 & 50 & 5 & 6 \\
Catechol 2,3-oxygenase & $m$-Xylene & 2760 & 1980 & 1600 & 1930 & 2450 \\
& $m$-Toluate & 1080 & 20 & 30 & 10 & 2 \\
& None & 100 & 80 & 100 & 2 & 6
\end{tabular}

* One unit $(U)$ is the amount of enzyme required to convert $1 \mu \mathrm{mol}$ substrate $\min ^{-1}$. The values of specific activity quoted are the mean of at least three determinations.

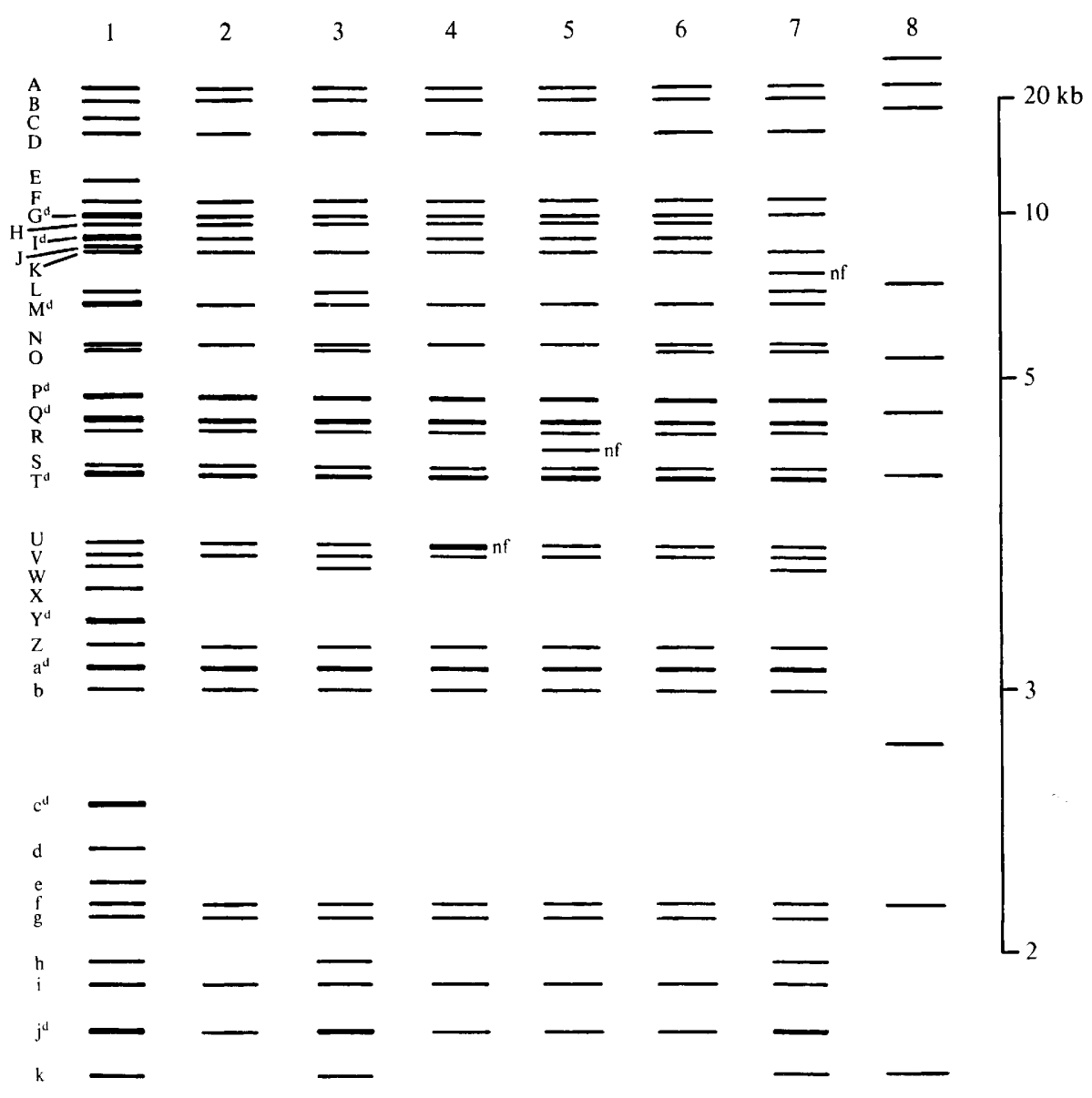

Fig. 2. Diagrammatic representation of bands visualized on agarose gels after electrophoresis of EcoRI digests of pWW20 and its derivatives (the plasmid numbers correspond to the MT numbers of the host strains). Double bands are shown as thick lines and are denoted with a superscript $d$ after the fragment letter. Novel fragments are denoted nf. Track 1, pWW20; track 2, pWW20-21; track 3, pWW20-22 (identical to pWW20-23); track 4, pWW20-24; track 5, pWW20-25; track 6, pWW20-26; track 7, pWW20-27; track 8, XhoI digest of pWW0 from $P$. putida mt-2 as a size standard (Downing \& Broda, 1979). 


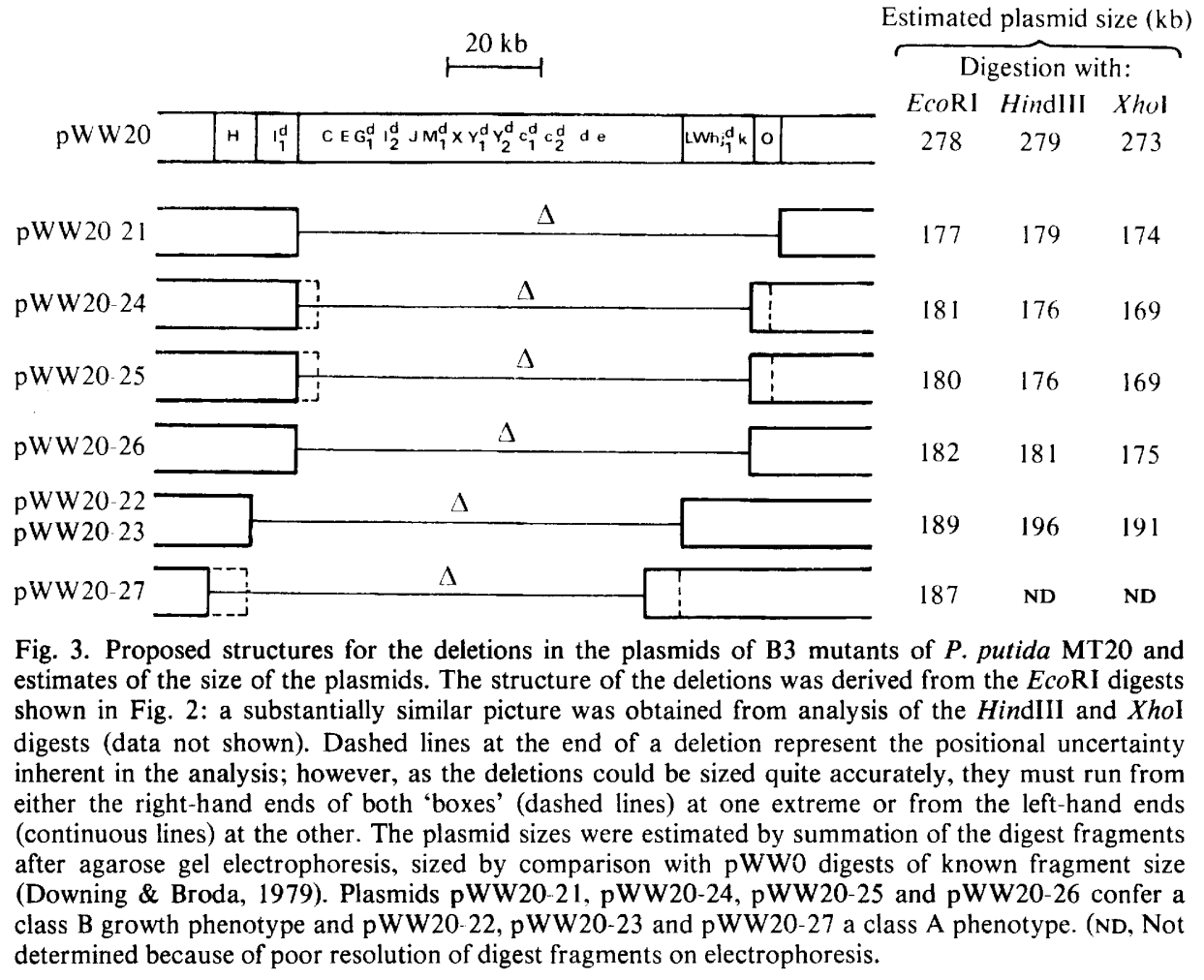

By these criteria, the original B3 strain would have been placed in class A (Worsey \& Williams, 1977).

Digestion of the plasmid DNA from strain MT20 and its derivatives with endonucleases HindIII, EcoRI or XhoI gave a complex mixture of fragments. Estimates of the number of fragments from digestion of pWW20 itself were: HindIII 52 (including 12 doubles, 1 triple), EcoRI 49 (11 doubles) and XhoI 51 ( 12 doubles, 1 triple). By sizing the fragments from their electrophoretic mobility compared with pWW0 digest fragments of known size (Downing \& Broda, 1979), the estimates of the total size of pWW20 were $279 \mathrm{~kb}$ (HindIII), $278 \mathrm{~kb}$ $(E c o R I)$ and $273 \mathrm{~kb}(X h o I)$. Errors in this analysis are likely to arise from (a) errors in sizing of individual fragments, particularly the larger ones, (b) assigning the wrong multiplicity to a particular band and (c) difficulties in resolving contiguous bands in congested areas of the gel.

Comparison of the digests of the plasmid DNA from the B3 mutants with that of pWW20 showed that all had undergone extensive deletion (Fig. 2). Estimates of the sizes of the plasmids from digests with the same three enzymes (Fig. 3) indicated deletions of about $90 \mathrm{~kb}$ in plasmids from class A strains and $100 \mathrm{~kb}$ in those from class B strains.

Apart from pWW 20-22 and pWW20-23 which were found to be identical, digests of all the other deleted plasmids differed in one or more fragments, showing that no specific excision event had occurred. All the plasmids had lost a common block of fragments amounting to $80 \mathrm{~kb}$ in EcoRI or XhoI digests and $72 \mathrm{~kb}$ in HindIII digests. The plasmids in class A strains had lost, in addition to the common block, a set of fragments different from the plasmids in class B strains: the pattern of loss was consistent with the deletions in class A continuing from the opposite end of the common block to those in class B. Using these data a partial ordering of some of the fragments was carried out, as shown in Fig. 3 for the EcoRI digest. A similar and remarkably consistent estimate of the relative positions of the deletions was obtained from the XhoI and HindIII digestions (data not shown). Undoubtedly there are errors in our interpretation of the plasmid structures, particularly where novel fragments occurred in the digests of deleted derivatives: this has partly been taken account of in the positional 
uncertainty in the termini of the deletions marked in Fig. 3. Because of the large size of the plasmids, we can see little hope at present of achieving a more complete analysis.

The evidence presented proves conclusively the earlier contention that the B3 phenotype results from deletion of pWW20 DNA (Worsey \& Williams, 1977), although the sizes of the deletions were unexpectedly large. If our earlier analysis of the regulation is correct, the $x y l S$ gene should lie in the deleted region and probably in the core fragments lost from all the plasmids. Since all the derivative plasmids are non-conjugative, presumably one or more tra genes also lie in that region. We have also demonstrated that extension of the deletion to one side of the common region (arbitrarily assigned to the right in Fig. 3), as in the class B strains, reduces the level to which benzyl alcohol dehydrogenase and benzaldehyde dehydrogenase, but not catechol 2,3-oxygenase, can be induced. Presumably, therefore, some other gene which affects their expression but is not absolutely essential lies in this right-hand region.

These results reinforce others from this laboratory which show the facility with which degradative plasmid structures can change under different nutritional conditions (Jeenes et al., 1982; Jeenes \& Williams, 1982). The loss of DNA from pWW20 appears to be more like that from the xylenol degradative plasmid (Hopper \& Kemp, 1980; Wheatcroft \& Williams, 1981), which readily undergoes a variety of non-specific deletions during growth on non-selective media to give a xylenol-negative phenotype, than the very specific excision undergone by pWWO on benzoate selection (Bayley et al., 1977). However, the high frequency of occurrence of B3 segregants, comparable after benzoate selection with plasmid-free segregants (Worsey \& Williams, 1977), suggests a high degree of structural instability which might well be the result of the presence of particular DNA elements which facilitate the observed deletions.

\section{REFEREN CES}

Bayley, S. A., Duggleby, C. J., Worsey, M. J., Williams, P. A., Hardy, K. G. \& Broda, P. (1977). Two modes of loss of the TOL function from Pseudomonas putida mt-2. Molecular and General Genetics 154, 203-204.

Downing, R. \& BRoDA, P. (1979). A cleavage map of the TOL plasmid of Pseudomonas putida mt-2. Molecular and General Genetics 177, 189-191.

HOPPER, D. J. \& KEMP, P. D. (1980). Regulation of enzymes of the 3,5-xylenol-degradative pathway in Pseudomonas putida: evidence for a plasmid. Journal of Bacteriology 142, 21-26.

JeEnes, D. J. \& Williams, P. A. (1982). Excision and integration of the degradative pathway genes from the TOL plasmid pWWO. Journal of Bacteriology (in the Press).

JeEnes, D. J., Reineke, W., KNACKMuss, H.-J. \& Williams, P. A. (1982). The TOL plasmid pWW0 in constructed halobenzoate degrading Pseudomonas strains: enzyme regulation and DNA structure. Journal of Bacteriology (in the Press).

WheAtcroft, R. J. \& Williams, P. A. (1981). Rapid methods for the study of both stable and unstable plasmids in Pseudomonas. Journal of General Microbiology 124, 433-437.
Williams, P. A. \& Murray, K. (1974). Metabolism of benzoate and methylbenzoates by Pseudomonas putida (arvilla) mt-2: evidence for the existence of a TOL plasmid. Journal of Bacteriology 120, 416423.

WiLliams, P. A. \& Worsey, M. J. (1976). Ubiquity of plasmids in coding for toluene and xylene metabolism in soil bacteria: evidence for the existence of new TOL plasmids. Journal of Bacteriology 125, 818-828.

Worsey, M. J. \& Williams, P. A. (1975). Metabolism of toluene and xylenes by Pseudomonas putida (arvilla) mt-2: evidence for a new function of the TOL plasmid. Journal of Bacteriology 124, 7-13.

Worsey, M. J. \& Williams, P. A. (1977). Characterisation of a spontaneously occurring mutant of the TOL20 plasmid in Pseudomonas putida MT20: possible regulatory implications. Journal of Bacteriology 130, 1149-1158.

Worsey, M. J., Franklin, F. C. H. \& Williams, P. A. (1978). Regulation of the degradative pathway enzymes coded by the TOL plasmid pWWO from Pseudomonas putida mt-2. Journal of Bacteriology 134, 757-764. 